\title{
THE HISTORY OF THE ESTABLISHMENT OF LAW NUMBER 9 OF 2013 REGARDING PREVENTION AND ERADICATION OF TERRORIST FINANCING
}

\author{
Listawati \\ Students of the Faculty of Law \\ Postgraduate Program of Law University of Indonesia, \\ University of Indonesia Campus, Salemba Central Jakarta \\ listawati.hutauruk@gmail.com
}

\begin{abstract}
To response to various acts of terror which occurred in various countries, the Financial Action Task Force (FATF) issued a policy in the form of a recommendations that contained a basic framework for the prevention and eradication of criminal acts of terroristfinancing that could be universally applied. This implementation of the FATF standard is obligatory for all countries including Indonesia. One component of Indonesia's commitment to implementing the FATF standard is evidenced by the Establishment of Law Number 9 of 2013 concerning the Prevention and Eradication of Terrorist Financing. In this paper, we will discuss the history of the formation of the TPPT Law detailed with 2 (two) main focuses, namely the process of criminalizing acts of terrorist financing in the TPPT Law and the factors that encouraged the Government of the Republic of Indonesia to draft special regulations related to anti-terrorist financing. The review of the complexity of the two focuses shows the strong commitment of the state to preventing (prevent) and eradicating ( to eradicate) of terrorist financing crimes
\end{abstract}

Keywords: History; Terrorist Financing; Terrorism

\section{Introduction}

Terrorism is an international crime that endangers world security and peace and is a gross violation of human rights, especially the right to live. Terrorism began to be widely discussed by the international community in 2001, when there was a hijacking of commercial airplanes which were flown into the World Trade Center (WTC) building in the United States. After the attack, local authorities began to focus on efforts to combat terrorist activities. ${ }^{1}$ The attack was also a trigger for the Financial Action Task Force (FATF), an international organization for the prevention and eradication of criminal acts of money laundering and terrorist financing, to issue 9 (nine) additional recommendations specifically related to the prevention and eradication of terrorist financing (9 SR) in $2001 .^{2}$

The nine additional recommendations provide a strong picture that in terrorist activities the element of financing is the main factor for every act of terror. The main objective of the 9 SRs is

\footnotetext{
${ }^{1}$ Maulana Rahmat, Politik Hukum Terhadap Tindak Pidana Teroris medan Pembaharuan Hukum Pidana Indonesia, Jurnal Wawasan Yuridika, Vol. 1 Number 2, September 2017, p. 156 http://ejournal.sthb.ac.id/index.php/jwy accessed September $1^{\text {st }}, 2018$

${ }^{2}$ FATF, FATF IX Special Recommendations, http://www.fatfgafi.org/publications/fatfrecommendations/documents/ixspecialrecommendations.html accessed September $1^{\text {st }}$, 2018.
} 
to become an international standard that can be used to block the access of terrorists and terrorist organizations to the financial system. ${ }^{3}$ This is in line with what was stated by Lucy Komisar as quoted by Sutan Remy Sjahdeni that the network of terrorists throughout the world depend on the system of secrecy of international banks and corporations to hide and divert their money. ${ }^{4}$

A year after the terrorist attacks that occurred in the United States, Indonesia experienced the same threat of terror through a series of bombings in Bali in 2002 with approximately 200 victims. The majority of those killed were Australian citizens. ${ }^{5}$ This then prompted the government to issue Government Regulation Number 1 of 2002 concerning the Eradication of Terrorism which was later passed into Law Number 15 of 2003. In addition to the aim of filling a legal vacuum in prosecuting terrorism, the regulation also reflected the government's efforts to comply with FATF 9 SR regarding the ban on terrorist financing as stipulated in Article 11 and Article 13 letter a of the Government Regulation.

Furthermore, in 2003 the government's efforts to comply with FATF 9 SRs were strengthened with the enactment of Law Number 25 of 2003 concerning Amendments to Law Number 15 of 2002 concerning Money Laundering which stipulates that assets used for terrorism activities are equated as the result of terrorism (Article 2 paragraph (2)) and make the act as one of the acts of violence originating from the crime of money laundering.

However, based on the results of the mutual evaluation review conducted by FATF against Indonesia in 2008, Indonesia is considered to have many weaknesses, especially related to the implementation of the FATF 9 SRs. This paper will discuss the history of the establishment of Law Number 9 of 2013 concerning the Prevention and Eradication of Terrorist Financing through 2 (two) research questions as follows:

1) What is the process of criminalizing the financing of terrorism in Indonesia?

2) What factors have prompted the government to form Law Number 9 of 2013 concerning the Prevention and Eradication of Terrorist Financing?

\footnotetext{
${ }^{3}$ Indonesia, Naskah Akademik Rancangan Undang-Undang tentang Pencegahan dan Pemberantasan Tindak Pidana Pendanaan Terorisme, p. 5

${ }^{4}$ Sutan Remy Sjahdeni, Seluk Beluk Tindak Pidana Pencucian Uang dan Pembiayaan Terorisme (Jakarta: Pustama Utama Grafiti, 2004) p. 289

${ }^{5}$ Maulana Rahmat, Politik Hukum Terhadap Tindak Pidana Teroris medan Pembaharuan Hukum Pidana Indonesia, p. 156.
} 


\section{Discussion}

\subsection{The Process of Criminalization of Terrorist Financing Acts}

Criminalization is the process of setting an act that was not originally a criminal offense into a crime. Criminalization arises when an action is detrimental to the community but there is no law to regulate it (there is a legal vacuum) so that, it encourages the criminalization of the act. $^{6}$ Criminalization policy is part of criminal policy by using the means of criminal law (penal), because it is a part of "criminal law policy" (penal policy). ${ }^{7}$ Sudarto as quoted by Sugeng Tirtoyo, argues that in the process of criminalization, there are several things that need to be considered, namely the use of criminal law must be in line with the national development goals which realize justice, prosperous, materially, and spiritually based on Pancasila. actions will be criminalized must be "undesirable actions", namely actions that bring harm (material and spiritual) to citizens; the use of criminal law must take into account the principle of costs and results (cost and benefit principle) and pay attention to the capacity or ability of the work force of the law enforcement elements. ${ }^{8}$

The same thing was stated by Mardjono Reksodiputro, namely to test a criminalization of the formulation of a criminal act, a number of principles need to be considered, namely: ${ }^{9}$ First, the principle that the loss described by the act must be reasonable, while this loss can have a moral aspect and be a public issue. The moral aspect of losses incurred due to acts of terrorism can be illustrated in a situation where people who have donated funds for religious or social obligations, but the funds are misused by others for the purpose of terrorist financing. Efforts to stop the terrorist financing have not only become a domestic issue but have become a global issue. The issuance of UN Security Council Resolution No. 1373 in 2001, was an international effort to prevent and eradicate the crime of terrorist financing. Second, the principle of no tolerance for these acts is an assessment of the occurrence of losses, which is based on respect for freedom and individual responsibility. The principle of tolerance in the sense that the community cannot tolerate acts of terrorist financing because the act of terrorist financing which then enables acts of terrorism which can cause enormous losses to the community in the form of

\footnotetext{
${ }^{6}$ Rizanizarli, Kriminalisasi di Luar KUHP dan Implikasi Terhadap Hukum Acara Pidana, Kanun Jurnal Ilmu Hukum, No. 63 Th. XVI (August 2014), p. 283.

${ }^{7}$ Rizanizarli, Kriminalisasi di Luar KUHP, p. 283.

${ }^{8}$ Sudarto dalam Barda Nawawi Arif, Bunga Rampai Kebijakan Hukum Pidana, Cetakan Kedua Edisi Revisi (Bandung: PT Citra Aditya Bakti, Bandung, 2002), p. 90.

${ }^{9}$ Mardjono Reksodiputro, Catatan tentang Kiminalisasi, Politik Kriminal, dan Asas-Asasnya, (the paper were presented at the Focused Group Discussion in The Indonesian Financial Transaction Reports and Analysis Centre, Jakarta, January $5^{\text {th }}, 2008$ ), in Indonesia, Academic Paper of Bill on Prevention and Eradication of Criminal Act of Terrorist Financing, p. 44.
} 
assets and human beings. Third, the principle of subsidiarity before an act is declared a criminal act, it should be noted whether the provisions of the law violated by the act can still be protected by other means, criminal law is only ultimum remedium. In the context of the crime of terrorist financing, the use of criminal law is appropriate considering that there is no other way to protect the legal interests of the community other than by using criminal law. Fourth, the principle of proportionality where there must be a balance between the losses described with the limits given by the principle of tolerance and with the reaction or crime given. The principle of proportionality as a requirement for criminal policy can be illustrated by the balance between losses according to the limits of the principle of tolerance and the reaction or crime that will be given. The threat of criminal sanctions is an effective means of reducing losses caused by the act of terrorist financing. Fifth, the principle of legality where it is necessary to consider whether the action can be formulated well so that the legal interests to be protected can be achieved and include the relationship with mistakes which are the main joints of crime. The principle of legality will be fulfilled through the formulation of clear and concrete laws. Sixth, the principle of effectiveness relating to the ability of law enforcement and its effectiveness. The principle of effectiveness can be fulfilled in the case when formulating a criminal act that has a prediction in its law enforcement practices.

As stated earlier, the criminalization of acts of terrorist financing has actually been regulated in Article 11 and Article 13 letter a of Act Number 15 of 2003 concerning the Establishment of Government Regulation Number 1 of 2002 concerning the Eradication of Terrorism into Law. But in the law, the act of terrorist financing is criminalized as a criminal act of terrorism. This is not in line with international standards issued by the FATF and the International Convention on the Eradication of Terrorist Financing which obliges the state to separate terrorist financing from criminal acts of terrorism.

Based on FATF international standards and international conventions, the approach used in the anti-terrorist financing regime is the same as the approach in the anti-money laundering regime, namely the approach follow the money. This is very different from the concept in Law No. 15 of 2003 which still uses the concept of following the suspect.

In Article 1 paragraph (1) of the TPPT Law the definition of terrorist financing is:

"...all actions in the context of providing, collecting, giving or lending funds, both directly and indirectly, with the intention that they be used and/or known to be used to carry out activities of terrorism, by terrorist organizations, or for terrorism. 
Based on this definition, in general the analysis of terrorist financing covers 3 (three) main aspects, namely efforts to raise funds, to move funds and to use funds. ${ }^{10}$ From the aspect of fundraising, fundraising can be carried out in various ways, which include funding through legal or legal sources, non-profit organizations, crowd funding methods, and sources of funds that are not illegal or illegitimate from the proceeds of crime. ${ }^{11}$

Legal or legal sources of funds can come from donations of members or sympathizers, pension funds, loans, small business ventures such as the sale of small-scale telephone vouchers, the travel agents business or muslim clothing sales. Besides that, terrorist financing can also be carried out through non-profit organizations. There are a large number of non-profit organizations that accessible and potentially have the capacity to raise large amounts of funds that are vulnerable to abuse such as terrorism financing. ${ }^{12}$ Fund raising is now also starting now to take advantage of social media to raise funds through crowd funding or fundraising from the community where the funds can be channeled directly through bank accounts. Changes in the pattern of funding of terrorism have occurred since 2015. ${ }^{13}$ However, digital information collected from social media from access to fundraising can be used to help prevent terrorist financing activities and provide opportunities for detection. ${ }^{14}$

Illegal sources of funds include illegal oil sales, bank robberies, gold shop robberies, taxes and extortion, sales of antiques, kidnappings and ransom. ${ }^{15}$

Furthermore, from the aspect of transferring funds, terrorist groups prefer ways that are not detected by law enforcement officials and in particular by financial regulators. ${ }^{16}$ According to Shima D Keene terrorists like the use of formal and informal financial systems as tactics to obscure the origin of the funds and the final recipients of these funds. ${ }^{17}$ Examples of the use of

\footnotetext{
${ }^{10}$ FATF-GAFI, Terrorist Financing, (Paris, Financial Action Tas Force(FATF) GAFI, 2008)

${ }^{11}$ Agus Santoso, Sylvia Windya Laksmi, Regional Terrorism Financing Risk Assesment Framework: Southest Asia and Australia, Counter Terrorist Trends and Analysisi Journal, Vol. 8, October 10 ${ }^{\text {th }}, 2016$, Singapore: RSISNanyang Technological University, p. 21.

${ }^{12}$ Agus Santoso, Sylvia Windya Laksmi, Regional Terrorism, Counter Terrorist Trends and Analysis Journal, p. 21

${ }^{13}$ Kristian Erdianto, PPATK: Kelompok Teroris Manfaatkan Media Sosial untuk Cari Dana, https://nasional.kompas.com/read/2017/11/30/17140831/ppatk-kelompok-teroris-manfaatkan-media-sosial-untukcari-dana accessed September $1^{\text {st }}, 2018$

${ }^{14}$ Agus Santoso, Sylvia Windya Laksmi, Regional Terrorism, Counter Terrorist Trends and Analysis Journal, p. 21.

${ }^{15}$ Glori K Wadrianto, Inilah 6 Sumber Dana Utama Kelompok Teroris ISIS, https://internasional.kompas.com/read/2016/09/10/11522621/inilah.6.sumber.dana.utama.kelompok.teroris.isis accessed September $1^{\text {st }}, 2018$.

16 Sylvia Windya Laksmi, Perempuan dan Pendanaan Terorisme: Menelusuri Motif di Balik Isu Radikalisme, Indonesian Financial Intelligence Institute Magazine, Vol. 01, September 2018.

${ }^{17}$ Shima D. Keenan, Threat Finance: Disconectingthe Lifeline of Organised Crime and Terrorism; Gower, 2012), https://books.google.co.id/books/about/Threat_Finance.html?id=ePtuAQAACAAJ\&redir_esc=y $\quad$ accessed September $1^{\text {st }}, 2018$.
} 
formal financial systems such as account opening, credit card usage, electronic money including the use of cryptocurrencies and informal uses such as remittances through hawala are considered more practical and reliable with shipping costs that tend to be cheaper than formal money transfer companies. ${ }^{18}$

Lastly from the aspect of use by terrorist groups. The funds collected were eventually used for 5 (five) main interest categories, namely for operational activities, propaganda and recruitment, military training, compensation for members' salaries, and social activities. ${ }^{19}$ The FATF study mentions that money generated by terrorist groups with the greatest value is used for propaganda and recruiting new members or sympathizers, as well as for terrorist group social activities. $^{20}$

Based on these three aspects, it can be said that these funds are "blood" which supports the crime of terrorism itself. This shift in the approach to eradicate terrorism is due to the many phenomena that have been discovered when conducting terrorism investigations themselves, one of which is the sources of the funds that come from accounts that are not known or sent by the main terrorist funders. ${ }^{21}$ According to Barda Nawawi Arief, as quoted by Randy Pradityo, such an approach is an integral part of the reasoning and non-reasoning policies, such as breaking the chain of funds flow, as a preventive measure for prevention efforts. ${ }^{22}$

The approach of follow the money is carried out through analysis of financial transactions as a way to look for perpetrators and criminal acts committed. ${ }^{23}$ Analysis of financial transactions is also carried out to detect the flow of funds used or suspected to be used for terrorism activities. To optimize the implementation of the approach, follow the money the government established the Financial Transaction Reports and Analysis Center (PPATK) based on The Act Number 15 of 2002 concerning Money Laundering which has a strategic role as a focal point in handling the financing of terrorism in Indonesia. The Financial Transaction Reporting and Analysis Center has the authority to receive and request suspicious financial transaction information or reports related to terrorist financing from the reporting party, conduct

\footnotetext{
${ }^{18}$ Shima D. Keenan, Threat $\quad$ Finance, https://books.google.co.id/books/about/Threat_Finance.html?id=ePtuAQAACAAJ\&redir_esc=y

${ }^{19}$ Sylvia Windya Laksmi, Perempuan dan Pendanaan Terorisme.

${ }^{20}$ FATF, Emerging Terrorist Risk 2015; http://www.fatf-gafi.org/media/fatf/documents/reports/Emerging-TerroristFinancing-Risks.pdf accessed September $1^{\text {st }}, 2018$.

${ }^{21}$ Randy Pradityo, Kebijakan Hukum Pidana Dalam Upaya Penanggulangan Tindak Pidana Pendanaan Terorisme, Jurnal Rechtsvinding Media Pembinaan Hukum Nasional, Vol. 5 Number 1, April 2016, p. 23.

${ }^{22}$ Barda Nawawi Arief dalam Randy Pradityo, Kebijakan Hukum Pidana, p. 23.

${ }^{23}$ Pusat Pelaporan dan Analisis Transaksi Keuangan, Modul Penanganan Tindak Pidana Pencucian Uang dan Tindak Pidana Asal, (Jakarta: Pusat Pelaporan dan Analisis Trasaksi Keuangan, 2012), p.23
} 
an analysis of the information and then forward the results of the analysis in the form of financial intelligence to authorized law enforcement agencies and judicial institutions. ${ }^{24}$ In addition PPATK is also given the authority to cooperate with relevant authorities such as the Police, the State Intelligence Agency, the National Agency for Combating Terrorism, and Customs and Excise to anticipate finacing of terrorism by utilizing couriers. ${ }^{25}$

Thus the approach of follow the money involves all components starting from the reporting party, namely financial service providers and providers of goods and / or services, supervisory and regulatory agencies, law enforcement officers, and the existence of an international cooperation mechanism in the form of exchanging information with other countries.

Furthermore, some acts that were criminalized based on the TPPT Law became criminal acts of terrorist financingnamely Article 4 "Every person who intentionally provides, collects, gives or lends funds both directly and indirectly, with the intention of being used in whole or in part to commit acts of terrorism, be punished because of committing a criminal act of terrorist financing with a maximum imprisonment of 15 (fifteen) years and a fine of a maximum of Rp.1,000,000,000 (one billion rupiah) ". Crimes that are the same as Article 4 are also imposed on perpetrators who commit conspiracy, trials, or assistance to commit criminal acts of terrorist financing. Different criminal threats are imposed on everyone who acts as an intellectual actor in terrorist financing activities, namely imprisonment for life or imprisonment for a maximum of 20 (twenty) years.

Terrorist financing carried out by Corporations then imposes penalties on Corporations and / or Corporate Control Personnel. The criminal threat of fines imposed on the Corporation is no more than $\mathrm{Rp} \mathrm{100,000,000,000} \mathrm{(one} \mathrm{hundred} \mathrm{billion} \mathrm{rupiah).} \mathrm{In} \mathrm{addition} \mathrm{to} \mathrm{receiving} \mathrm{criminal}$ penalties for fines, the corporation can also be subject to additional criminal penalties, namely freezing partially or wholly of the corporation's activities, revoking licenses and entering the prohibited list of corporations, dissolving corporations, seizing corporate assets for the state, taking over corporations by the state; and / or court decisions.

The criminalization of acts of terrorist financing in Article 4, Article 5 Article 6, and Article 8 of the the Act on Terrorism Fundings Offencesalso aims to separate terrorism from terrorist financing and improve the regulation of elements of terrorist financing as stipulated in

\footnotetext{
${ }^{24}$ Muhammad Jasuma Fadholi, Analisis Kerjasama Pusat Pelaporan dan Analisis Transaksi Keuangan (PPATK) dalam The Egmont Group Terhadap Penanganan Pendanaan Terorisme di Indonesia, Journal of International Relations, Vol. 3 No. 4, 2017, p. 117.

${ }^{25}$ Muhammad Jasuma Fadholi, Analisis Kerjasama, p. 117
} 
Article 11 and Article 13 letter a of Law No. 15 of 2003 concerning Stipulation of Government Regulation Number 1 of 2002 concerning Eradication of Terrorism into a Law based on the objectives of criminalization policies and international provisions and recommendations.

\subsection{Driver factors for the Establishment of Law Number 9 of 2013 concerning Prevention and Eradication of Financing Terrorism}

\section{a. Indonesia entered into the Non-Cooperative Countries and Terraces (NCCTs) List and Enforcement of Enactment of The Act Number 15 Year 2002 concerning Money} Laundering

The history of the formation theAct on Terrorism Fundings Offencesis inseparable from the inclusion of Indonesia in the "black list" or Non-Cooperative Countries (NCCTs) and as a country with a high risk and not cooperating with money laundering crimes based on the results of FATF evaluation. The first evaluation resulted in 15 (fifteen) countries being included in the NCCT's list as a country which was seen as having the potential as a place for money laundering practices and in June 2001 Indonesia was included in the NCCT's list. ${ }^{26}$

Based on the results of an evaluation carried out by FATF in 2001, the various weaknesses identified by FATF in general were the absence of legislation that criminalized money laundering, the financial intelligence unit (FIU), the absence of suspicious reporting of financial transactions to be submitted to FIU, the application of know your customer principles only applies to the banking industry, and lack of international cooperation. ${ }^{27}$

Indonesia was included in the NCCTs list, making the Indonesian government and the House of Representatives immediately take strategic steps including the enactment of the 2002 Law No. 15 concerning Money Laundering (TPPU Law).

The enactment of the Act Number 15 of 2002 concerning Money Laundering does not necessarily exclude Indonesia from NCCT's. FATF considers that there are 10 (ten) weaknesses in Indonesia that have not met the international best practice standards, namely ${ }^{28}$ first, there is no comprehensive regulatory framework available in relation to anti-money laundering standards for non-bank financial institutions, such as insurance and stock brokers; second, there is no provision regarding the fit and proper test for non-bank financial institutions; third, there are no provisions regarding know your customer for non-bank financial institutions; fourth, the need to

\footnotetext{
${ }^{26}$ Yunus Husein, Bunga Rampai Anti Pencucian Uang, (Jakarta: Book Terrace\& Library, 2007), p. 131

${ }^{27}$ Yunus Husein, Nahkoda PPATK 9 Tahun, (Jakarta: PPATK, 2011), p. 39

${ }^{28}$ Yunus Husein, Bunga Rampai Anti Pencucian Uang, p. 134
} 
expand the notion of suspicious financial transactions in the Act on Terrorism Fundings Offences, so that it includes the obligation to report transactions suspected of using proceeds of crime; fifth, there is no provision for a ban on tipping off in the Act on Terrorism Fundings Offences; sixth, the need to shorten the suspicious reporting period of financial transactions from the PJK to PPATK because 14 (fourteen) days is considered too long; seventh, the necessity of abolishing the limit (threshold) proceeds of crime (proceeds of crime) in the AML Law is set at Rp.500 million; eighth, there is the potential to not be able to freeze and confiscate the proceeds of crime which are under the limit of Rp.500 million; ninth, there are no provisions governing mutual legal assistance; tenth, PPATK has not yet operated as an FIU.

At that time the FATF asked Indonesia to be able to complete the amendment to theAct on Terrorism Fundings Offences he before the FATF plenary session held on the 1-3 October 2003 which would review the status of countries in NCCTs, including Indonesia. If Indonesia could not meet the target of improving the Act on Terrorism Fundings Offences, Indonesia would be subject to sanctions (counter measures) that had previously been imposed on Nauru and Ukraine. $^{29}$

As long as Indonesia was still an uncooperative country, the cost of financial transactions in international trade with other countries will be even greater due to the risks that are considered to be high, resulting in rejection by other countries of letters of credit issued by banks from countries with sanctions including Indonesia. In addition, the relationship between national banking correspondence and international banking will be cut off. The government would also find it difficult to obtain international assistance both bilaterally and multilaterally. The worst possible impact of NCCTs is the reluctance of foreign investors to enter the country if sanctioned by FATF. For example, American countries prohibit employers from cooperating with countries subject to sanctions under the law. ${ }^{30}$

\section{b. The enactment of Act Number 25 of 2003 concerning Amendments to Act Number 15 of 2002 concerning Money Laundering}

To overcome various weaknesses (deficiencies) in Act Number 15 of 2002, the Indonesian government then took steps and made an effort to improve the existing TPPU Law. On October 13, 2003 the Government and the Parliament Issues Act Number 25 of 2003 concerning Amendments to Act Number 15 Year 2001 concerning Money Laundering. However, it also did

\footnotetext{
${ }^{29}$ Yunus Husein, Nahkoda PPATK 9 Tahun, p. 40

${ }^{30}$ Yunus Husein, Nahkoda PPATK 9 Tahun, p. 42.
} 
not enabled Indonesia to leave NCCTs because the FATF asked Indonesia to be able to demonstrate the success of the new TPPU Law in resolving major cases. Based on the FATF Plenary Session in Paris on June $30^{\text {th }}-J u l y 2^{\text {nd }} 2004$, Indonesia was still included on the NCCTs because the FATF considered that Indonesian regulations had not yet been implemented by the law enforcers. ${ }^{31}$

\section{c. Indonesia Exit the Non-Cooperative Countries and Terraces (NCCTs) List}

After struggling for more than 3 years, Indonesia finally exited the NCCTs in 2005. The annual FATF meeting in Paris decided that Indonesia should be excluded from the NCCTs report on the implementation of Plan periodically.

Then in 2008, FATF through the APG again conducted an evaluation (mutual evaluation) on the development of the fulfillment of 40 Recommendations and 9 SRs. In the mutual evaluation process, the toughest challenges faced by Indonesia were the fulfillment of 9SR. The challenges in question included: ${ }^{32}$ there were various terrorist organizations that were very active in raising funds and carrying out terrorist activities in Indonesia and in a number of jurisdictions in Southeast Asia; there were a number of names and parties still identified as affiliated with Al Qaeda and the Taliban based on the UN Security Council Resolution (Resolution) 1267; jemaah Islamiah (JI) was still suspected of being a terrorist threat in Indonesia; a number of people have been arrested or convicted as terrorists.

The regulation in Act Number 15 of 2002 was considered not in accordance with the FATF 9 SR. One example was that even although Indonesia has criminalized acts that provide funds for terrorist activities, as long as these actions are not specifically referred to as criminal acts of financing terrorism, the FATF considered Indonesia had not criminalized these actions.

The results of mutual evaluation review in 2008 was as follows: ${ }^{33}$

1. In SR I related to the Implementation of UN Instruments, Indonesia received a Not Positive rating with the weakness that Indonesia had not fully implemented the UN TF Convention and had not implemented Resolution 1267 and Resolution 1373.

2. In SR II related to Criminalize TF, Indonesia receive an assessment Partly Compliant with the weakness, Indonesia has not criminalized Terrorist Financing including not having regulated corporate criminal liability that is financing terrorism by using criminal law.

\footnotetext{
${ }^{31}$ Yunus Husein, Nahkoda PPATK 9 Tahun, p. 42

${ }^{32}$ Indonesia, Naskah Akademik Rancangan Undang-Undang tentang Pencegahan dan Pemberantasan Tindak Pidana Pendanaan Terorisme, p. 26

${ }^{33} \mathrm{APG}, \quad$ Mutual Evaluation Review Indonesia, 2008, http://www.apgml.org/includes/handlers/getdocument.ashx?d=58c99328-6e45-4238-b3af-670ac33f2689 accessed May $7^{\text {th }}, 2018$
} 
3. In SR III related to Freezing and Consolidation of Terrorist Assets, Indonesia received an assessment of Not Compliant because Indonesia had not had an effective system to implement Resolution 1267 and Resolution 1373.

4. In SR IV related to Suspicious Transaction Reporting, Indonesia received an assessment Partly Compliant because Indonesia had no rules specifically which stated the obligation to report suspicious financial transactions related to terrorist financing from the reporting party.

5. At SR V related to International Cooperation, Indonesia received an assessment Partly Compliant with the weakness of having to have dual criminality for the Crime of Terrorist Financing.

6. In related SR VI AML requirements for money / value transfer services, Indonesia received the assessment of Not Compliant with many money remittances that were not registered in BI and Indonesia did not have a system to monitor the informal money remittance.

7. on SR VII-related Wire Transfer Rules, Indonesia receive an assessment of Not Compliant. Indonesia did not yet have a specific arrangement regarding wire transfers that require banks to request complete information about the sender.

8. In SR VIII related to Non-Profit Organizations, Indonesia received an assessment of NonCompliance. Indonesia did not yet have a strategy to identify the risks of regional funds, weak transparency and a good governance system in the NPO sector (community organizations).

9. In SR IX related to Cash Couriers, Indonesia received an assessment Partly Compliant with the weakness that the Bearer Negotiable Insurers (BNI) were not yet regulated and it was not yet clear who had the authority to hold BNI fraudulent or empty.

Based on the mutual evaluation the review in 2008 above showed that Indonesia's fulfillment of 9 SRs was still lacking. There are 5 Non-Compliant (NC) ratings. Thus, it can be illustrated that most of the standards in 9 SR have not been regulated in Indonesia.

\section{d. Indonesia is Part of the FATF Public Statement}

On February 16, 2012 FATF placed Indonesia in the FATF category Public Statement. ${ }^{34}$ The FATF Public Statement is to identify jurisdictions that have deficiencies in the

\footnotetext{
${ }^{34}$ Yuliana Adhika Risang Putri, Peran Rekomendasi Financial Action Task Force Dalam Penanganan Pendanaan Terorisme di Indonesia, Journal of International Relations, Volume 1 Number 2, 2015, p. 91
} 
implementation of AML / CFT and counter measures which will be applied to those jurisdictions, as well as jurisdictions that have deficiencies where there has been no progress to correct them or there is no commitment to action plans to eliminate deficiencies. ${ }^{35}$

The entry of Indonesia on the FATF Public Statement was not because of the fulfillment of the FATF's recommendations regarding the implementation of prevention and eradication of non-money laundering crimes, but because Indonesia is still considered to have deficiencies in fulfilling the 9 SRs. The impact of the inclusion of Indonesia in the FATF Public Statement includes the implementation of Enhanced Due Diligence (EDD) ${ }^{36}$ by foreign financial service providers $(\mathrm{PJK})$ on all financial transactions originating from Indonesia. ${ }^{37}$ The impact on the development of the domestic economy, among others, inhibits financial transactions from and to Indonesia that are real time and eliminates the trust of the world community to make transactions or invest in Indonesia. ${ }^{38}$

\section{e. Indonesia Exits from FATF Public Statement and Establishment of Act Number 9 of 2013 concerning Prevention and Eradication of Terrorist Financing}

As a positive response to Indonesia being part of the FATF Public Statement, the government took concrete steps by drafting an initial draft bill on the Prevention and Eradication of Terrorist Financing. The bill was then included in the list of National Legislation Programs (Prolegnas) for 2010-2014 and became one of the Priority Draft of 2012. ${ }^{39}$

According to Finance Minister Agus Martowardojo, the discussion on the bill was carried out in addition to fulfilling the FATF 9 SR and was also very important as a condition of eligibility in conducting international financial transactions. If Indonesia did not have the law at the time of review in 2013 it would reduce the standard of eligibility for Indonesian transactions. $^{40}$

The drafting of the bill became increasingly strategic after Indonesia ratified the International Convention for the Suppression of the Financing of Terrorism, 1999 (UN TF) with Act No. 6 of 2006 concerning Ratification of the International Convention for the Suppression of

\footnotetext{
${ }^{35}$ Muhammad Rakhmanaji, Upaya Indonesia dalam Pencegahan dan Pemberantasan Pendanaan Terorisme Agar Terhindar dari Sanksi FATF, (Tesis Universitas Indonesia, Jakarta, 2016), p. 85.

${ }^{36}$ In Enhanced Due Diligence meaning all finance transactions which come from Indonesia, $P J K$ is required to perform identification, verification and in depth monitoring. (see Muhammad Yusuf, Kapita Selekta,p. 40).

${ }^{37}$ Muhammad Yusuf, Kapita Selekta TPPU, (Jakarta: PPATK, 2016), p. 40

${ }^{38}$ Muhammad Yusuf, Kapita Selekta TPPU, p. 40

${ }^{39}$ Badan Legislasi, Baleg Sampaikan Usulan Perubahan Prolegnas, www.dpr.go.id accessed May $7^{\text {th }}, 2017$.

${ }^{40}$ Republika, RUU Pendanaan Terorisme, Negara G20 Punya Kecuali Indonesia, http://m.republika.co.id/amp_version/mexo8g accessed May $7^{\text {th }}, 2018$.
} 
the Financing of Terrorism, 1999. This ratification is a manifestation free and active Indonesian foreign policy demonstrating participates in efforts to eradicate all forms of crime both nationally and internationally through bilateral, regional and international cooperation. With the ratification of the international convention, Indonesia needs to make further arrangements in national law to implement the contents of the convention.

In 2012 the Government together with the Parliament Special Committee chaired by Adang Darajatun discussed the Bill on the Prevention and Eradication of Terrorist Financing. On February 11, 2013, all factions agreed on the substance of the bill. ${ }^{41}$ On March 13, 2013 establish an Act Number 9 of 2013 concerning Prevention and Eradication of Terrorist Financing was ratified. ${ }^{42}$ With the enactment of the the Act on Terrorism Fundings Offences, it is serious proof that Indonesia has actively participated in the prevention and eradication of criminal acts of terrorist financing and positive efforts to fulfill the SRs.

Positive advances made by Indonesia include the regulation of a comprehensive Act in terrorism funding offence and it's implementation that is directly carried out by stakeholders and law enforcement. This made Indonesia come out of the overall review in the International Cooperation Review Group on 22-23 June 2015 in Brisbane Australia. In the meeting, the Regional Review Group (RRG) FATF team evaluator reported to the ICRG session about the positive results in the evaluation process that had been carried out on Indonesia on 11-12 May 2015. Reports from RRG were appreciated by other countries such as Australia, Canada, The United States, Singapore, New Zealand, China, Italy, Japan, India, Russia, Norway and Turkey. These countries consider Indonesia to have a strong commitment in improving its weaknesses and is very responsive in responding to the dynamics and information in the field. ${ }^{43}$ The results of the evaluation, which underlies the plenary session of the International Cooperation Review Group (ICRG), stated that Indonesia was out of ICRG supervision and monitoring and was declared clean of non-compliant labels on the implementation of UN Security Council Resolution 1267 and $1373 .{ }^{44}$

\footnotetext{
${ }^{41}$ Markus Junianto Sihaloho, RUU Pendanaan Terorisme Siap Disahkan di Paripurna DPR, http://www.beritasatu.com/hukum/96142-ruu-pendanaan-terorisme-siap-disahkan-di-paripurnadpr.html?no direct=true accessed May $7^{\text {th }}, 2018$.

${ }^{42}$ Indonesia, Undang-Undang tentang Pencegahan dan Pemberantasan Tindak Pidana Pendanaan Terorisme, Law No. 9 Year 2013. LN No. 50 Year 2013, TLN No. 5406.

${ }^{43}$ Muhammad Yusuf, Kapita Selekta TPPU, p. 42.

${ }^{44}$ RI Director General of Multilateral Affairs Hasan Kleib, In the press conference held on Friday, June 262015 at PPATK http://www.ppatk.go.id/pages/detail/40/11682? reloaded = yes accessed May $7^{\text {th }}, 2018$.
} 


\section{Conclusion}

Based on the above analysis it can be concluded that the history of The Act Number 9 of 2013 concerning Prevention and Eradication of Terrorist Financing Crime is inseparable from the history of the development of the anti money laundering regime in Indonesia. In the process of criminalizing acts of terrorist financing, there has been a change of approach which originally used the follow the suspect to a follow the money approach. This is an effort to detect the flow of funds used or alleged to be used for terrorist activities and to find the perpetrators and criminal acts committed. The criminalization of acts of terrorist financing is regulated in Article 4, Article 5 Article 6, and Article 8 of the Act on Terrorism Fundings Offences. Criminalization in Act on Terrorism Fundings Offences improves the regulation of elements of terrorist financing as stipulated in Article 11 and Article 13 letter a of Act Number 15 of 2003 concerning Stipulation of Government Regulation Number 1 of 2002 concerning Eradication of Criminal Acts of Terrorism into Law.

Furthermore, the discussion regarding the factors that pushed the government to form the the Act on Terrorism Fundings Offenceswas explained through a description of a series of important events that took place in Indonesia that influenced government policies including the enacting of Act Number 15 of 2002 concerning Money Laundering and the amendments to Law No. 25 of 2003, Perpu No. 1 of 2002 concerning Eradication of Terrorism Crimes stipulated by The Act Number 15 of 2003, and the the Act on Terrorism Fundings Offences in an effort to combat terrorism crimes and meet the FATF standard.

Thus, the follow the money approach applied in the the Act on Terrorism Fundings Offences should be used as a guideline in the preparation and development of technical policies related to anti-terrorist financing in Indonesia. This technical policy is expected to increase effective cooperation among all stakeholders in an effort to prevent future acts of terrorism.

\section{References}

Agus Santoso dan Sylvia Windya Laksmi (2016). Regional Terrorism Financing Risk Assesment Framework: Southest Asia and Australia. Counter Terrorist Trends and Analysiss Journal, Singapore: RSIS-Nanyang Technological University. Vol. 8 (October).

APG, Mutual Evaluation Review Indonesia, 2008, http://www.apgml.org/includes/handlers/getdocument.ashx?d=58c99328-6e45-4238-b3af-670ac33f2689 
Badan Legislasi, Baleg Sampaikan Usulan Perubahan Prolegnas, www.dpr.go.id accessed May $7^{\text {th }}, 2017$.

Barda Nawawi Arif. Bunga Rampai Kebijakan Hukum Pidana, Cetakan Kedua Edisi Revisi. Bandung: PT Citra Aditya Bakti, 2002.

FATF, Emerging Terrorist Risk 2015; $\underline{\text { http://www.fatf- }}$ gafi.org/media/fatf/documents/reports/Emerging-Terrorist-Financing-Risks.pdf accessed September $1^{\text {st }}, 2018$

FATF, FATF IX Special Recommendations, gafi.org/publications/fatfrecommendations/documents/ixspecialrecommendations.html accessed September $1^{\text {st }}, 2018$.

FATF-GAFI, Terrorist Financing , (Paris, Financial Action Tas Force(FATF) GAFI, 2008.

Glori K Wadrianto, Inilah 6 Sumber Dana Utama Kelompok Teroris ISIS, https://internasional.kompas.com/read/2016/09/10/11522621/inilah.6.sumber.dana.utama.k elompok.teroris.isis accessed September $1^{\text {st }}, 2018$

Indonesia, Naskah Akademik Rancangan Undang-Undang tentang Pencegahan dan Pemberantasan Tindak Pidana Pendanaan Terorisme.

Indonesia, Undang-Undang tentang Pencegahan dan Pemberantasan Tindak Pidana Pendanaan Terorisme, UU No. 9 year 2013. LN No. 50 Year 2013, TLN No. 5406

Indonesia, Undang-Undang tentang Pengesahan International Convention for the Suppression of The Financing of Terrorism 1999, UU No. 6 year 2006, LN No.29 Year 2006, TLN No. 4617.

Indonesia, Undang-Undang tentang Perubahan Atas Undang-Undang Nomor 15 Year 2002 tentang Pencegahan dan Pemberantasan Tindak Pidana Pencucian Uang, UU No. 25 Year 2003, LN No. 108 Year 2003, TLN No. 4324.

Kristian Erdianto, PPATK: Kelompok Teroris Manfaatkan Media Sosial untuk Cari Dana, https://nasional.kompas.com/read/2017/11/30/17140831/ppatk-kelompok-terorismanfaatkan-media-sosial-untuk-cari-dana accessed September $1^{\text {st }}, 2018$

Maulana Rahmat (2017). Politik Hukum Terhadap Tindak Pidana Terorisme dan Pembaharuan Hukum Pidana Indonesia. Jurnal Wawasan Yuridika. Vol. 1 (No. 2 September).

Markus Junianto Sihaloho, "RUU Pendanaan Terorisme Siap Disahkan di Paripurna DPR." http://www.beritasatu.com/hukum/96142-ruu-pendanaan-terorisme-siap-disahkan-diparipurna-dpr.html?no_direct=true accessed May $7^{\text {th }}, 2018$. 
Muhammad Jasuma Fadholi (2017), Analisis Kerjasama Pusat Pelaporan dan Analisis Transaksi Keuangan (PPATK) dalam The Egmont Group Terhadap Penanganan Pendanaan Terorisme di Indonesia, Journal of International Relations, Vol. 3 No. 4.

Muhammad Rakhmanaji. "Upaya Indonesia dalam Pencegahan dan Pemberantasan Pendanaan Terorisme Agar Terhindar dari Sanksi FATF.”Tesis Universitas Indonesia. Jakarta, 2016.

Muhammad Yusuf. Kapita Selekta TPPU. Jakarta: PPATK, 2016.

Pusat Pelaporan dan Analisis Transaksi Keuangan, Modul Penanganan Tindak Pidana Pencucian Uang dan Tindak Pidana Asal, Jakarta: Pusat Pelaporan dan Analisis Trasaksi Keuangan, 2012.

Randy Pradityo (2016). Kebijakan Hukum Pidana Dalam Upaya Penanggulangan Tindak Pidana Pendanaan Terorisme. Jurnal Rechtsvinding Media Pembindaan Hukum Nasional. Vol 5 (No. 1, April).

Republika, RUU Pendanaan Terorisme, Negara G20 Punya Kecuali Indonesia, http://m.republika.co.id/amp_version/mexo8g

Rizanizarli (2014), Kriminalisasi di Luar KUHP dan Implikasi Terhadap Hukum Acara Pidana, Kanun Jurnal Ilmu Hukum, No. 63 Th. XVI (August).

Shima D. Keenan (2012), Threat Finance: Disconectingthe Lifeline of Organised Crime and Terrorism;

Gower. https://books.google.co.id/books/about/Threat_Finance.html?id=ePtuAQAACAAJ\&redir esc=y accessed September $1^{\text {st }}, 2018$.

Sutan Remy Sjahdeni. Seluk Beluk Tindak Pidana Pencucian Uang dan Pembiayaan Terorisme, Jakarta: Pustama Utama Grafiti, 2004.

Sylvia Windya Laksmi (2018). Perempuan dan Pendanaan Terorisme: Menelusuri Motif di Balik Isu Radikalisme. Indonesian Financial Intelligence Institute Magazine, Vol 01 (September).

Yuliana Adhika Risang Putri (2015). Peran Rekomendasi Financial Action Task Force Dalam Penanganan Pendanaan Terorisme di Indonesia. Journal of International Relations. Vol 1 (No. 2).

Yunus Husein. Bunga Rampai Anti Pencucian Uang. Jakarta: Book Terrace\& Library, 2007. Yunus Husein. Nahkoda PPATK 9 Year. Jakarta: PPATK, 2011. 